\title{
Comparing Tea Leaf Products and Other Forages for In-vitro Degradability, Fermentation, and Methane for Their Potential Use as Natural Additives for Ruminants
}

\section{Diky Ramdani1, Abdul S. Chaudhry², Iman Hernaman¹, and Chris J. Seal²}

${ }^{1}$ Faculty of Animal Husbandry, Universitas Padjadjaran, Jatinangor Campus, Sumedang 45363. Indonesia

${ }^{2}$ School of Agriculture, Food and Rural Development, Newcastle University, Newcastle upon Tyne NE1 7RU, UK

\section{Abstract}

Tea leaves are a rich source of plant secondary metabolites such as tannins and

Corresponding Author:

Diky Ramdani

diky.ramdani@unpad.ac.id

Received: 28 July 2017

Accepted: 14 September 2017

Published: 23 November 2017

Publishing services provided

by Knowledge E

(ㄷ) Diky Ramdani et al. This article is distributed under the terms of the Creative

Commons Attribution License, which permits unrestricted use and redistribution provided that the original author and source are credited.

Selection and Peer-review under the responsibility of the ICSAFS Conference Committee. saponins that have the potential to manipulate rumen fermentation and to lessen methane $\left(\mathrm{CH}_{4}\right)$ production.Samples of green tea $(\mathrm{GTL})$, black tea $(\mathrm{BTL})$, their spent leaves after water extraction (SGTL and SBTL), ryegrass hay $(R H)$, ryegrass silage (RS), paddy straws (PS), barley straws (BS), and wheat straws (WS) were compared for their rumen in-vitro organic matter degradability (IVOMD, g/kg DM), $\mathrm{pH}$, ammonia $\left(\mathrm{NH}_{3}, \mathrm{mg} / \mathrm{L}\right)$, total volatile fatty acids (tVFA, mmol/L), total gas production ( $\mathrm{tGP}, \mathrm{L} / \mathrm{kg}$ $\mathrm{OM})$, and methane output $\left(\mathrm{CH}_{4}, \mathrm{~L} / \mathrm{kg} \mathrm{OM}\right)$ after $28 \mathrm{~h}$ incubation with buffered rumen fluid under anaerobic conditions at $39^{\circ} \mathrm{C}$ in glass syringes. One-way ANOVA on Minitab 16 was used to examine differences between products at $P<0.05$ for four replicate samples. There were no differences between tea leaf products, $\mathrm{RH}$ and RS but the straws tended to have lower IVOMD compared with tea leaf products and other forages. GTL produced the lowest $\mathrm{NH}_{3}$ followed by BTL, SGTL, SBTL, and other forages. There were no differences between most tea leaf products, RH, RS, and the straws for tVFA concentration but PS and WS produced the lowest tVFA. GTL, SGTL, and RH had higher tGP than BTL, SBTL, and the straws but they had a lower tGP than RS. GTL, BTL, and SBTL produced similar levels of $\mathrm{CH}_{4}$ as the straws but this was less than RS and SGTL. The results suggest that if tea leaf products are included in the straw-based diets as natural feed additives, they may improve degradability, tVFA, $\mathrm{NH}_{3}$, and tGP production without increasing $\mathrm{CH}_{4}$ output. Low $\mathrm{NH}_{3}$ production for tea leaf products could be the sign of more by-pass protein to be absorbed in small intestine.

Keywords: Tea leafproducts, in-vitro measurements, and ruminants. 


\section{Introduction}

Teas and their spent tea leaves (STL) as residues are potentially good sources of protein, minerals, and plant secondary metabolites [1]. In ruminants, plant secondary metabolites such as phenols and tannins may increase the availability of rumen bypass protein and non-ammonia nitrogen $\left(\mathrm{NH}_{3} \mathrm{~N}\right)$ supply which can be absorbed in the small intestine due to their binding ability to plant proteins [2-5]. Although $\mathrm{NH}_{3}$ is an important source of $\mathrm{N}$ for rumen microbes, its over or fast production may exceed the ability of microbes to utilize it. This can lead to an excessive $\mathrm{NH}_{3}$ supply that after absorption through rumen wall can enter the blood stream, liver, and eventually excreted in urine as an $\mathrm{N}$ waste $[6,7]$. Tannins have the potential to reduce rumen $\mathrm{CH}_{4}$ production $[3,5]$. Similarly, tea saponins can reduce $\mathrm{CH}_{4}$ and $\mathrm{NH}_{3}$ productions [8-10] by reducing protozoa and the methanogenic activity of relevant microbes $[8,9] . \mathrm{CH}_{4}$ and $\mathrm{NH}_{3}$ are energetically wasteful end products of rumen fermentation so that the reduction in $\mathrm{CH}_{4}$ production in the rumen is assumed to be the reflection of more efficient feed utilization [8]. Agricultural activities are supposed to be responsible for 40-60\% of the total anthropogenic $\mathrm{CH}_{4}$ production while $25-40 \%$ of this comes from livestock sector, predominantly from ruminants through their eructation and manures [11-13]. $\mathrm{CH}_{4}$ production is also associated with the loss of gross energy by $2-12 \%$ [14]. Hence, $\mathrm{CH}_{4}$ mitigation in ruminants is an aim, not only for environmental advantage, but also for feed utilization efficiency. Lastly, if the chemical properties of tea products are able to manipulate rumen fermentation, these products can be used as a natural alternative to replace growth-promoting antibiotics that have been banned in the European Union since 2003 (1831/2003; EC, 2003) and which may also be banned in other countries such Asian Australasian in the future. Therefore, this study aimed to compare tea leaf products and other feeds for in-vitro degradability, fermentation, and $\mathrm{CH}_{4}$ production for their potential use to manipulate rumen fermentation.

\section{Material and Methods}

\subsection{Sample preparation}

Green (GTL) and black (BTL) tea leaves were obtained from a tea processing company (PT. Kabepe Chakra), located in Bandung, West Java, Indonesia. GTL was graded as Sow Mee (Code: SM \#315) and the black tea was graded as Broken Orange Pekoe Fanning (Code: BOPF \#355). STL were obtained by extracting $2.8 \mathrm{~g}$ of either green (SGTL) or black (SBTL) tea leaves in a fixed volume of $300 \mathrm{ml}$ of boiling water for 5 minutes. While samples of ryegrass hay (RH), ryegrass silage (RS), barley straws (BS), and wheat straws (WS) were collected from Cockle park farm, Newcastle University UK 
during April 2012. The sample of paddy straws (PS, variety IR50) was obtained from Bangladesh in a dried form. Before chemical analysis, all samples were oven dried at $60^{\circ} \mathrm{C}$ and ground through $1 \mathrm{~mm}$ sieve using a sample mill.

\subsection{Chemical analysis}

The AOAC methods [15] were used to determine dry matter (DM), ash, organic matter $(\mathrm{OM})$ and ether extract (EE) while total nitrogen $(\mathrm{N})(\mathrm{N} \times 6.25=$ Crude Protein, $\mathrm{CP})$ was analyzed by Elementar Vario Macro Cube (Elementar, Hanau Germany). The neutral detergent fibre (NDF) content was determined according to Van Soest [16] but without using amylase, sodium sulphite, and dekalin while acid detergent fibre (ADF) was determined as reported by Van Soest [17]. The NDF and ADF contents were calculated by excluding ash. Metabolisable energy (ME) was calculated by using the formula of Khan and Chaudhry [18].

\subsection{Buffered inoculum}

The rumen fluid (RF) for this in-vitro experiment was collected on 5 June 2013 from two freshly slaughtered grass-fed lambs (Texel Cross) from a local slaughterhouse located at Buradon, Newcastle upon Tyne UK.Immediately after slaughtering, the rumen was cut and RF was directly filtered through two layers of muslin cloth on a large funnel connected to pre-warm insulated thermos flasks (Thermos Ltd, UK) until fully filled and closed tightly allowing anaerobic conditions to be maintained inside the flasks, and then transported directly to the Laboratory for immediate use within 1 hour of collection.After thatRF was mixed, quantified, and transferred quickly, under filtration oftwo layers of muslin cloth, into the pre-warmed dark bottles (2.5 L capacity) containing buffer solution [19] at 1:2 ratio (RF:buffer) while kept in a water-bath $\left(39^{\circ} \mathrm{C}\right)$. The bottles containing buffered RF were then purged with $\mathrm{CO}_{2}$ to remove oxygen and tightly closed with a dispenser ( $50 \mathrm{ml}$ capacity, Fisher Scientific UK). The pH of each buffered inoculum was adjusted around $7 \pm 0.2$ using HCL drop wise.

\subsection{In-vitro incubation}

About $200 \pm 4 \mathrm{mg}$ of each sample was transferred into a $50 \mathrm{ml}$ glass syringe (SAMCO, UK), lubricated with Vaseline, and fitted with a 4 way-male-slip stopcock (Cole Palmer Instrument, UK). About $20 \mathrm{ml}$ buffered inoculums was added to each syringe which was closed and placed in a shaking water bath at $39^{\circ} \mathrm{C}$. Total gas production (tGP) in each syringe was measured every two hours for up $28 \mathrm{~h}$.After incubation, most of the warm water in the water bath was replaced with sufficient ice to stop further 
fermentation in the syringes. About $15 \mathrm{ml}$ gas from each incubated syringe was then transferred into another clean syringe from where the gas was transferred to a $12 \mathrm{ml}$ evacuated gas tube (Labco Exetainer, Labco Ltd, UK) by using a needle being attached to the stopcock for $\mathrm{CH}_{4}$ analysis. Furthermore, all the contents in each syringe (inoculum and the residues) were transferred into a pre-weighted tube (polyethylene, 50 $\mathrm{ml}$ capacity) for the $\mathrm{pH}, \mathrm{NH}_{3}, \mathrm{VFA}$, and in-vitro organic matter digestibility (IVOMD) measurements. $\mathrm{pH}$ was measured directly by a $\mathrm{pH}$ meter ( $\mathrm{pH}$ 309, Hanna Instruments Ltd, UK). All tubes were then centrifuged and subjected to sample preparations for volatile fatty acids (VFA) and $\mathrm{NH}_{3}$ analyses. All the remaining residual particles in the syringes were water washed into the corresponding tubes containing the residues. These undigested residues were dried at $80^{\circ} \mathrm{C}$ for IVOMD determination as described by Khan and Chaudhry [17]. Two blank representatives were run alongside the samples in each trial and the blank values were used to correct the degradability and tGP estimations.

\subsection{VFA and $\mathrm{NH}_{3}$ analyses}

After centrifugation, $2 \mathrm{ml}$ of each supernatant was pipetted into a capped-container and mixed with $0.5 \mathrm{ml}$ of deproteinising solution containing 200g/L metaphosphoric acid and $10 \mathrm{mmol} / \mathrm{L}$ of crotonic acid as an internal standard for VFA determination. About $2 \mathrm{ml}$ of each sample was then transferred into $2 \mathrm{ml}$ gas chromatograph (GC) vial ready for analysis along with a mixed VFA standard. A mixed standard solution contained ( $\mathrm{mmol} / \mathrm{L}$ ) acetate (50), propionate (20), iso-butyrate (10), n-butyrate (10), iso-valerate (10), n-valerate (10), and crotonic acid (10). All individual VFA standards were purchased from Sigma-Aldrich, UK. A set of GC, Shimadzu GC-2014 (Kyoto, Japan) with a capillary GC column $(15 \mathrm{~m} \times 0.53 \mathrm{~mm} \times 1.20 \mu \mathrm{m}$ film thickness) (Econo-Cap EC1000, Altech, UK) and an auto injector (Shimadzu, AOC-20i) was connected to Shimadzu $\mathrm{GC}$ solution software which controlled almost all the operations of this VFA analysis. Purified helium was utilized as a carrier gas with a head pressure of approximately $3.4 \mathrm{kPa}$ and a column flow of $0.85 \mathrm{ml} / \mathrm{min}$. Peaks were detected by flame ionization detection (FID). A split injection system on an auto sampler was used with a split ratio of 34.5:1 and an injector temperature of $250^{\circ} \mathrm{C}$ while the detector temperature was $275^{\circ} \mathrm{C}$. A $1 \mu \mathrm{l}$ sample injection was applied when the initial temperature of the column was at $120^{\circ} \mathrm{C}$. It was then raised at $10^{\circ} \mathrm{C} /$ minute to $240^{\circ} \mathrm{C}$ in $12 \mathrm{~min}$. Furthermore, the temperature was then decreased at $60^{\circ} \mathrm{C} / \mathrm{min}$ back to $120^{\circ} \mathrm{C}$ in 2 min to give a final gradient with the total runtime of 17 minutes. The data, including peak areas and chromatograms were extracted from Shimadzu GC solution software after the analysis. Total VFA (tVFA) was calculated as the sum of acetate, propionate, iso-butyrate, $n$ butyrate, iso-valerate, and n-valerate. Meanwhile, $\mathrm{NH}_{3}$ determination was prepared 
by pipetting $2 \mathrm{ml}$ of each supernatant into a capped-container and acidifying them with $2 \mathrm{ml}$ of $1(\mathrm{~N}) \mathrm{HCl}$. NH $\mathrm{NH}_{3}$ was analysed by Pentra 400 (Horriba Ltd, Kyoto, Japan) with calibrated standards of $\mathrm{NH}_{3}-\mathrm{N}$ at 25,50 , and $100 \mu \mathrm{g} / \mathrm{ml}$ in pure distilled water.

\section{6. $\mathrm{CH}_{4}$ determination}

$\mathrm{CH}_{4}$ determination was performed using a GC-MS (Fisons $8060 \mathrm{GC}$, Italy) using split injection $\left(150^{\circ} \mathrm{C}\right.$ ) linked to a Fisons MD $800 \mathrm{MS}$ (electron voltage $70 \mathrm{eV}$, emission current $150 \mu \mathrm{A}$, source current $600 \mu \mathrm{A}$, source temperature $200^{\circ} \mathrm{C}$, multiplier voltage $300 \mathrm{~V}$, interface temperature $150^{\circ} \mathrm{C}$ ). The acquisition was controlled by a Compaq Deskpro computer using Xcalibur software (Xcalibur Inc. USA) in a full scan mode (1.0-151.0 amu/sec). A headspace gas sample of $100 \mu$ l using a $100 \mu \mathrm{l} \mathrm{GC} \mathrm{syringe} \mathrm{(SGE} \mathrm{Europe} \mathrm{Ltd,}$ UK) was injected in duplicate in a split mode into the HP-PLOT-Q capillary column (30m $\times 0,32 \mathrm{~mm}$ i.d) packed with $20 \mu \mathrm{m}$ Q phase (J\&W Scientific, USA) of the GC. The GC was held isothermally at $35^{\circ} \mathrm{C}$ with Helium as the carrier gas (flow $1 \mathrm{ml} / \mathrm{min}$, pressure of $65 \mathrm{kPa}$ and open split at $120 \mathrm{ml} / \mathrm{min})$. The chromatograms of the separated gase $\left(\mathrm{CH}_{4}\right)$ were integrated and quantified. A calibrated mixture gas of $60 \% \mathrm{CH}_{4}$ in $\mathrm{CO}_{2}$ (Scientific \& Technical gases Ltd, UK) was run along with the samples at 20,40,60, 80, and 100 $\mu l$ injections to suit the standard curve calibrations.

\subsection{Statistical analysis}

Chemical compositions of tea leaf products and forages were averagely calculated from triplicate analysis while one-way analysis of variance (ANOVA) on Minitab 16 software was used to compare different tea leaf products and other forages (4 replicates each) for their in-vitro degradability, fermentation, and $\mathrm{CH}_{4}$ output. Differences were considered significant if $P<0.05$.

\section{Results and Discussion}

Chemical compositions ( $\mathrm{g} / \mathrm{kg} \mathrm{DM}$ ) of various tea leaf products and other feed types were described in Table 1. Tea leaf products had greater CP than RH, RS, and the straws. Tea leaf products had also higher ME but lower Fibre fractions than the straws. Here, the straws had the lowest $C P$ and ME but highest in Fibre fractions compared with tea leaf product and other forages. In addition, GTL and BTL had less fibre fractions, higher ash but almost the same EE and ME contents than their corresponding STL.

There were no differences between tea leaf products, RH, and RS on IVOMD but the straws tended to have lower IVOMD than tea leaf products and other forages. There were no differences between tea leaf products and most of forages on rumen 
TABLE 1: Chemical compositions of tea leaf products and other forages ( $g / \mathrm{kg} \mathrm{DM})$.

\begin{tabular}{|c|c|c|c|c|c|c|c|c|c|}
\hline Forages & $\mathrm{DM}$ & $\mathrm{OM}$ & Ash & $\mathrm{CP}$ & $\mathrm{EE}$ & NDF & $A D F$ & $A D L$ & ME \\
\hline GTL & 937 & 938 & 61.8 & 240 & 20.8 & 254 & 211 & 37.6 & 7.08 \\
\hline BTL & 942 & 939 & 61.4 & 242 & 12.6 & 323 & 309 & 27.4 & 6.40 \\
\hline SGTL & 134 & 957 & 43.3 & 246 & 23.1 & 405 & 294 & 40.3 & 7.39 \\
\hline SBTL & 126 & 961 & 38.7 & 234 & 13.5 & 474 & 410 & 44.5 & 6.59 \\
\hline $\mathrm{RH}$ & 840 & 908 & 92.4 & 200 & 20.2 & 649 & 507 & 435 & 6.79 \\
\hline RS & 325 & 917 & 83.4 & 136 & 14.0 & 595 & 427 & 379 & 7.60 \\
\hline PS & 944 & 818 & 182 & 60.4 & 9.9 & 787 & 684 & 598 & 4.01 \\
\hline BS & 866 & 948 & 51.6 & 49.1 & 18.1 & 846 & 672 & 594 & 4.34 \\
\hline WS & 903 & 938 & 62.5 & 38.1 & 46.1 & 843 & 590 & 530 & 4.43 \\
\hline
\end{tabular}

$\mathrm{pH}$ except GTL had lower $\mathrm{pH}$ than the straws. GTL produced the lowest $\mathrm{NH}_{3}$ followed by BTL, SGTL, SBTL, and other forages. There were no differences between most tea leaf products, $\mathrm{RH}, \mathrm{RS}$, and the straws for tVFA concentration but PS and WS produced the lowest tVFA. GTL, SGTL, and RH had higher tGP than BTL, SBTL, and the straws but they had lower tGP than RS. GTL, BTL, and SBTL produced similar levels of $\mathrm{CH}_{4}$ as the straws but this was less than RS and SGTL.

Based on this in-vitro experiment, the mean IVOMD of tea leaf products was higher than the straws but slightly lower than the RH and RS. The tea leaf products were degraded more in the rumen than the straws. The rate of tea leaf product degradation was close to those of higher quality forages such as RH and RS. This higher degradability was in line with the higher $\mathrm{CP}$ and $\mathrm{ME}$ but lower fibre contents in the tea leaf products alongside RH and RS compared with the straws. This observation also confirmed that GTL were more degradable in the rumen than BTL counterpart which might have acquired more resistant components due to the 'Maillard browning reactions' during black tea manufacturing. As expected, the higher nutritive values and IVOMD of tea leaf products than straws resulted in a significant greater tGP of tea leaf products in comparison with the straws. It was good to observevariable tGP as its volume changed with the change in the substrate type. In fact, tGP has been reported to be positively correlated with ME content in the diet and ME was positively correlated with the $\mathrm{CP}$ and $\mathrm{EE}$ contents $[16,19]$. Meanwhile, lower $\mathrm{NH}_{3}$ for most tea leaf products than other forages could be attributed to their high tannin contents [1] that have the ability to modify the microbial activity in the rumen. Tannins can bind and protect plant proteins from rumen digestion and thus reduce $\mathrm{NH}_{3}$ production [2-5].

Although original tea leaves such as GTL and BTL had higher rumen IVOMD and tGP than the straws, their $\mathrm{CH}_{4}$ outputs as $\mathrm{L} / \mathrm{kg} \mathrm{OM}$, were not different. This means that the concentration of $\mathrm{CH}_{4}$ in the total gas for GTL and BTL were significantly lower than that 
TABLE 2: Means ( \pm SD) for rumen IVOMD (g/kg DM), pH, tVFA (mmol/L), $\mathrm{NH}_{3}(\mathrm{mg} / \mathrm{L}), \mathrm{tGP}(\mathrm{L} / \mathrm{kg} \mathrm{OM})$, and $\mathrm{CH}_{4}(\mathrm{~L} / \mathrm{kg} \mathrm{OM})$ of tea leaf products and other forages at $28 \mathrm{~h}$ of incubation.

\begin{tabular}{|c|c|c|c|c|c|c|}
\hline rages & IVOMD & $\mathrm{pH}$ & A & $\mathrm{NVI}_{3}$ & tGP & $\mathrm{CH}_{4}$ \\
\hline GTI & $679^{a b} \pm 80.0$ & .09 & $39.1^{a b} \pm 6.61$ & & & $18.1^{b c d} \pm 2.36$ \\
\hline$\Gamma \mathrm{L}$ & $623^{a b c} \pm 40.8$ & $6.74^{a b c} \pm 0.09$ & $36.9^{a b} \pm 4.78$ & $89.3^{b} \pm 9.18$ & $124^{d} \pm 13.8$ & $16.5^{b c d} \pm 2.48$ \\
\hline jTL & $670^{a b c} \pm 53.0$ & $6.66^{b c} \pm 0.03$ & $40.2^{a} \pm 6.47$ & $104^{b} \pm 11.0$ & & $22.4^{b} \pm 2.34$ \\
\hline BTL & & $6.77^{a b c} \pm 0.03$ & $41.9^{a} \pm 2.01$ & $127^{a} \pm 8.62$ & & $19.1^{b c} \pm 1.85$ \\
\hline 4 & $709^{a} \pm 39.2$ & $6.69^{b c} \pm 0.10$ & $40.5^{a} \pm 2.53$ & $129^{a} \pm 4.00$ & $163^{b} \pm 1.12$ & $22.1^{b} \pm 0.62$ \\
\hline S & & & & & & \pm 3.37 \\
\hline$S$ & & $6.86^{a} \pm 0.03$ & $28.5^{b} \pm 3.30$ & $142^{a} \pm 4.40$ & $86.0^{e} \pm 4.82$ & $13.7^{d} \pm 1.13$ \\
\hline$D C$ & $575^{b c} \pm 60.9$ & $6.80^{a b} \pm 0.07$ & $35.3^{a b} \pm 3.15$ & $142^{a} \pm 3.47$ & $88.8^{e} \pm 5.86$ & \\
\hline VS & $573^{b c} \pm 40.2$ & $6.77^{a b c} \pm 0.02$ & $28.4^{b} \pm 6.20$ & $138^{a} \pm 1.91$ & $98.3^{d e} \pm 8.11$ & $15.2^{c d} \pm 1.11$ \\
\hline$=101$ & 32.0 & 0.03 & 2.27 & 3.74 & 6.42 & 0.97 \\
\hline Value & 0.01 & 0.001 & $<0.001$ & $P<0.001$ & $P<0.001$ & $\mathrm{P}<\mathrm{C}$ \\
\hline
\end{tabular}

Means with different letters in the same column are significantly different; SD, standard deviation; SEM, standard error of mean; GTL, green tea leaves; BTL, black tea leaves; SGTL and SBTL, green and black spent tea leaves; RH, ryegrass hay; RS, ryegrass silage; PS, paddy straws; BS, barley straws; WS, wheat straws.

of the straws. However, the ability to reduce $\mathrm{CH}_{4}$ concentration by STL was poorer. Perhaps, this was due to lower tannins and saponins in the STL compared with the original tea leaves [1]. Tannins can reduce rumen $\mathrm{CH}_{4}$ production $[3,5]$ and so saponins [8-10] by reducing protozoa and the methanogenic activitiesintherumen $[8,9]$.

\section{Conclusion}

Tea leaves have the potential as natural feed additives for ruminants to reduce rumen $\mathrm{NH}_{3}$ but increasing potential by-pass proteins and improving the degradability of low quality straws without affecting $\mathrm{CH}_{4}$ output. Spent tea leaves can also improve the degradability of the straws but their ability to reduce $\mathrm{NH}_{3}$ and $\mathrm{CH}_{4}$ concentration depends upon their tannin and saponin contents.

\section{Acknowledgements}

This study was funded by The Directorate General of Higher Education, Ministry of Research, Technology, and Higher Education, Indonesia via Full PhD Scholarship of Diky Ramdani, PhD at Newcastle University UK. 


\section{References}

[1] Ramdani, D., Chaudhry, A.S., Seal, C.J. 2013. Chemical Composition, Plant Secondary Metabolites, and Minerals of Green and Black Teas and the Effect of Different Teato-Water Ratios during Their Extraction on the Composition of Their Spent Leaves as Potential Additives for Ruminants. Journalof Agricultural and Food Chemistry. 61: 4961-4967.

[2] McSweeney, C.S., Palmer, B., McNeill, D.M., Krause, D.O. 2001. Microbial Interactions with Tannins: Nutritional Consequences for Ruminants. Animal Feed Science and Technology, 91: 83-93.

[3] Makkar, H.P.S. 2003. Effects and Fate of Tannins in Ruminant Animals, Adaptation to Tannins, and Strategies to Overcome Detrimental Effects of Feeding Tannin-Rich Feeds. Small Ruminant Research, 49: 241-256.

[4] Min, B.R., Barry, T.N., Attwood, G.T., McNabb, W.C. 2003. The Effect of Condensed Tannins on the Nutrition and Health of Ruminants Fed Fresh Temperate Forages: $A$ Review. Animal Feed Science and Technology, 106: 3-19.

[5] Mueller-Harvey, I. 2006. Review Unravelling the Conundrum of Tannins in Animal Nutrition and Health. Journal of Science Food and Agriculture, 86: 2010-2037.

[6] Attwood, G.T., Klieve, A.V., Ouwerkerk, D., Patel, B.K.C. 1998. AmmoniaHyperproducing Bacteria from New Zealand Ruminants. Applied Environmental Microbiology, 64: 1796-1804.

[7] Szumacher-Strabel, M., Cieślak, A. 2010. Potential of Phytofactors to Mitigate Rumen Ammonia and Methane Production. Journal of Animal Feed Science, 19: 319337.

[8] Hu, W.-L., Liu, J.-X., Ye, J.-A., Wu, Y.-M., Guo, Y.-Q. 2005. Effect of Tea Saponin on Rumen Fermentation In Vitro. Animal Feed Scienceand Technology, 120: 333-339.

[9] Guo, Y.-Q., Liu, J.X., Zhu, W.Y., Denman, S.E., McSweeney, C.S. 2008. Effect of Tea Saponin on Methanogenesis, Microbial Community Structure and Expression of mcraGene, in Cultures of Rumen Micro-Organisms. Letter of Applied Microbiology, 47: 421-426.

[10] Mao, H.-L., Wang, J.-K., Zhou, Y.-Y., Liu, J.-X. 2010. Effects of Addition of Tea Saponins and Soybean Oil on Methane Production, Fermentation and Microbial Population in the Rumen of Growing Lambs.Livestock Science,129: 56-62.

[11] Moss, A.R., Jouany, J.P., Newbold, J. 2000. Methane Production by Ruminants: Its Contribution to Global Warming. Annales de Zootechnie, 49: 231-253.

[12] Boadi, D., Benchaar, C., Chiquette, J., Massé, D. 2004. Mitigation Strategies to Reduce Enteric Methane Emissions from Dairy Cows: Update Review. Canadian Journal of Animal Science, 84: 319-335. 
[13] Attwood, G., McSweeney, C. 2008. Methanogen Genomics to Discover Targets for Methane Mitigation Technologies and Options for Alternative $\mathrm{H}_{2}$ Utilisation in the Rumen. Australian Journal of Experimental Agriculture, 48: 28-37.

[14] Johnson, K.A., Johnson, D.E. 1995. Methane Emissions from Cattle. Journal of AnimalScience, 73: 2483-2492.

[15] AOAC.2005. Animal Feeds(Chapter 4), in "Official Methods of Analysis of AOAC International". In: William Horwitz, George W. Latimer and Nancy J. Wendt Thiex (Eds).AOAC International, Gaithersburg, Maryland, USA.

[16] Van Soest, P.J., Robertson, J.B., Lewis, B.A. 1991. Methods for Dietary Fiber, NeutralDetergent Fiber and Nonstarch Polysaccharides in Relation to Animal Nutrition. Journal of Dairy Science, 74: 3583-3597.

[17] Van Soest, P.J. 1973. Collaborative Study of Acid-Detergent Fiber and Lignin.Journal of AOAC International, 56: 781-784.

[18] Menke, K.H., Steingass, H. 1988. Estimation of the Energetic Feed Value Obtained from Chemical Analysis and In Vitro Gas Production Using Rumen Fluid. Animal Research Development, 28: 7-55.

[19] McDougall, E.I. 1948. Studies on Ruminant Saliva: the Composition and Output of Sheep's Saliva. Biochemistry Journal,43: 99-100.

[20] Khan, M.M.H., Chaudhry, A.S. 2010. Chemical Composition of Selected Forages and Spices and the Effect of These Spices on In Vitro Rumen Degradability of Some Forages. Asian Australasian Journal of Animal Science, 23: 889-900. 